Article -Smart energy

\title{
Current Panorama and 2025 Scenario of Photovoltaic Solar Energy in Brazil
}

Isabela Valpecovski Urbanetz ${ }^{1^{*}}$

https://orcid.org/0000-0003-3757-8546

\section{Allana de Moura Netto ${ }^{1}$}

https://orcid.org/0000-0002-5787-9947

\section{Bruno Scolari ${ }^{1}$}

https://orcid.org/0000-0001-9695-5650

Vicente Leite ${ }^{2}$

https://orcid.org/0000-0002-8790-519X

Jair Urbanetz Junior ${ }^{1}$

https://orcid.org/0000-0001-9355-1730

1 Universidade Tecnológica Federal do Paraná, Curitiba, Brazil; 2 Polytechnic Institute of Bragança, Bragança, Portugal;

Received: 2018.11.05; Accepted: 2019.07.26.

* Correspondence: isabela_valp@hotmail.com; Tel.: +351932 439825

\section{HIGHLIGHTS}

- Installed capacity of photovoltaic systems in Brazil.

- Forecast of growth of photovoltaic systems in Brazil until 2025.

Abstract: The photovoltaic solar energy in Brazil was boosted by Normative Resolution No. 482/2012 of ANEEL, which regulated the micro and mini generation in the compensation system, and by the specific auctions for photovoltaic plants carried out by the federal government. However, the country still has little representation of the solar energy in its electrical matrix, about $0.13 \%$, with approximately $1 \%$ of the installed capacity of electric power generators considering all the sources, both values refer to the year 2017. In the initial moments of a technology, its growth occurs irregularly and because there is little installed capacity, any added value can cause abrupt variations in the percentage from one year to another, that is, its growth still does not follow a sustainable standard, which should be regularized around the year 2025, following the worldwide trend of growth of approximately $30 \%$ each year. As a scenario for 2025, the total power of the PVSGC in Brazil will be approximately $75.6 \mathrm{GWp}$ which will represent $98.3 \mathrm{TWh}$ of electric energy produced by this source, considering the estimated electric energy demand for 2025 of 800 TWh, will result in the contribution of $12.3 \%$ of the energy by solar photovoltaic source.

Keywords: Photovoltaic Solar Energy, Energy Scenario, Installed Capacity. 


\section{INTRODUCTION}

In 2012, with Normative Resolution No. 482/2012 of the National Electric Energy Agency (ANEEL), photovoltaic solar energy came to be an important option for the production of electricity cleanly and sustainably. Especially, Photovoltaic Systems Grid Connected (PVSGC) have full use of the energy generated by not requiring energy storage equipment, such as batteries. The PVSGC uses the concessionaire as a supplier at times without production and as a warehouse at times of high productivity [1] [2].

The growth in the use of PVSGC in Brazil occurred timidly in the early years, followed by significant growth in the following years. This growth was of such intensity that it exceeded the expectations made concerning the generation distributed by ANEEL in Technical Note $n{ }^{\circ} 0056 / 2017-S R D$. The actual value of the installed power until July 31 , 2018, the cut-off date defined for article analysis, was higher than that predicted for the entire year [3] [4] [5]. It is important to note that in the year 2017, the year of publication of the Technical Note, the installed power value for a micro and mini photovoltaic generation was also exceeded, supported by ANEEL Normative Resolution No. 482/2012.

Due to the inconsistencies of the studies as mentioned earlier, it is necessary and important to carry out a new analysis of the current state and the growth of this constantly expanding energy source.

The present article has the purpose of presenting the current installed capacity of the Photovoltaic Systems Grid Connected (PVSGC) in Brazil. The study presented includes both mini and micro generation, supported by Normative Resolution $482 / 2012$, as well as centralized generation.

To characterize the current Brazilian scenario, the energy produced annually is demonstrated, as this energy represents a percentage in the Brazilian energy matrix and the proportion of this source concerning the other sources of electricity generation in the country.

Subsequently, through a critical and careful analysis of current data and forecasts, a possible scenario is presented with estimates for the following years up to the year 2025 .

\section{MATERIAL AND METHODS}

For the development of this research is going to be used data from the PVSGCs provided by ANEEL in the Generation Information Bank (BIG) and the reports on the Distributed Generation Consumer Units registered as micro or mini generation, as well as reports from the Energy Research Company (EPE) which present scenarios of electric energy consumption in Brazil for the coming years.

Based on this information are presented graphs with the data compiled, exposing the current scenario of photovoltaic solar energy in Brazil, to understand how the development of this technology in the country occurs.

In the formation of the future scenario is considered a predicted power installed based on current growth. Posteriorly, to an expectation of energy production in accordance with the desired power, considering that the annual YIELD in the Brazilian territory varies from $1,100 \mathrm{kWh} / \mathrm{kWp}$ to $1,800 \mathrm{kWh} / \mathrm{kWp}$ [6], an annual YIELD of 1,300 kWh / kWp has been allocated to obtain an estimated value of energy that will be produced in each year analyzed. These values, together with the total load forecasts in Brazil in the EPE studies, will result in the percentage of energy produced by this source in the country's annual demand. 


\section{RESULTS}

To begin this analysis it is important to realize that the increase in the amount of SFVCRs in the country did not occur spontaneously. This was driven by Normative Resolution No. 482/2012 of ANEEL, which regulated the energy compensation system, similar to the net metering. In addition to these facts, the large-scale study and information on this theme have contributed to the creation of incentives and scientific development on related topics such as clean and sustainable energy generation. These documents are extremely important for the whole of Brazilian society.

The installed capacity of mini and micro-generation PVSGCs has tripled, being shown in the graph of Figure 1, considering the installed power since 2012, the year in which a possibility of distributed generation appeared. Although distributed generation encompasses energy sources other than photovoltaic, the latter has the greatest influence on the amount of distributed generation due to its low operating maintenance and relative ease of installation.

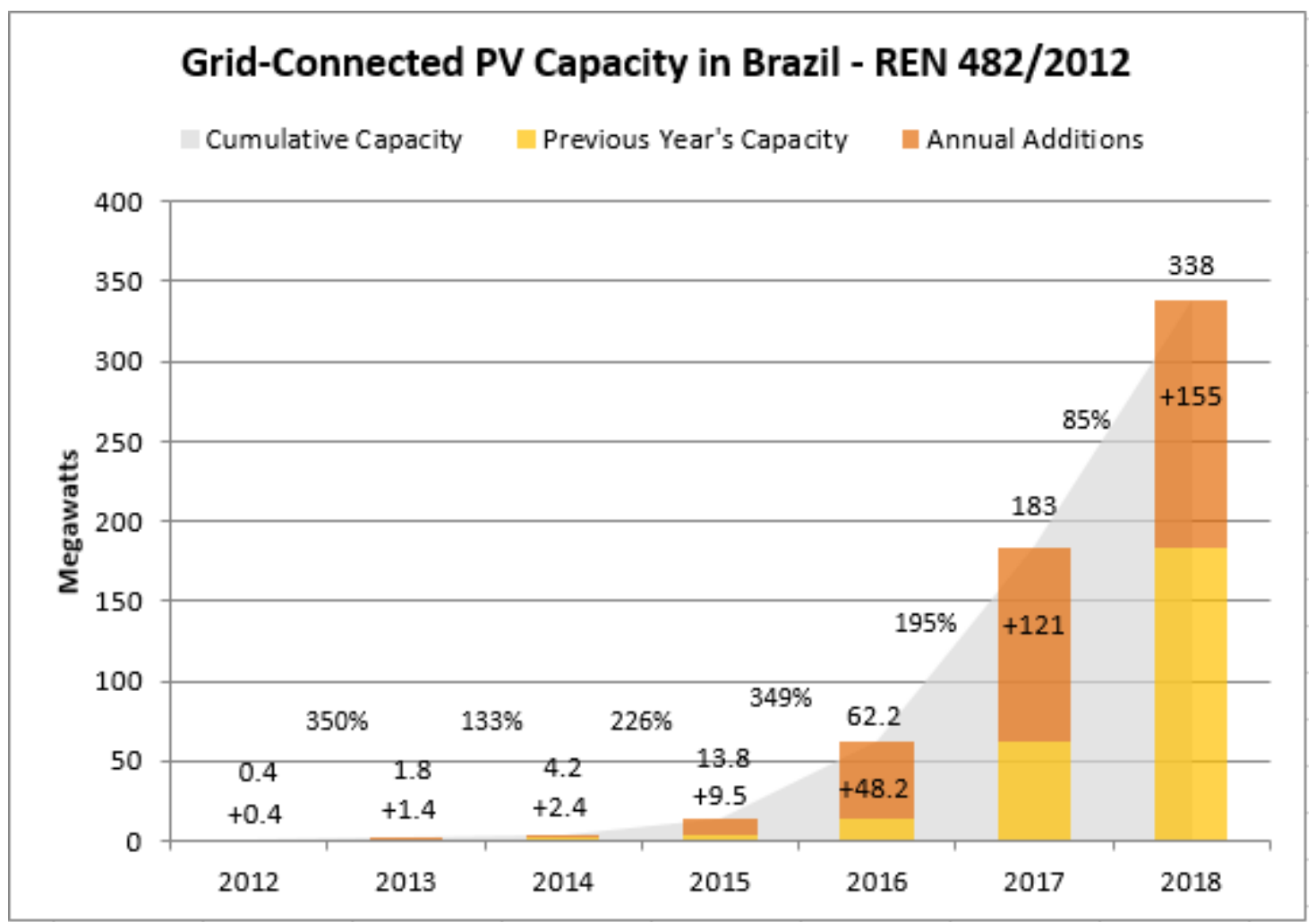

Figure 1 - Evolution of the installed power of micro and mini photovoltaic generation in Brazil. Source: Data compiled by the authors based on [4].

On the other hand, in centralized generation plants, the increase in installed power is more irregular, since it is linked to the existence of energy auctions by the federal government. There was a large increase in these plants in the year 2017, resulting in an impact on the total power superior to that of the distributed generation. This abrupt change in the year 2017 is explained in the graph in Figure 2. 


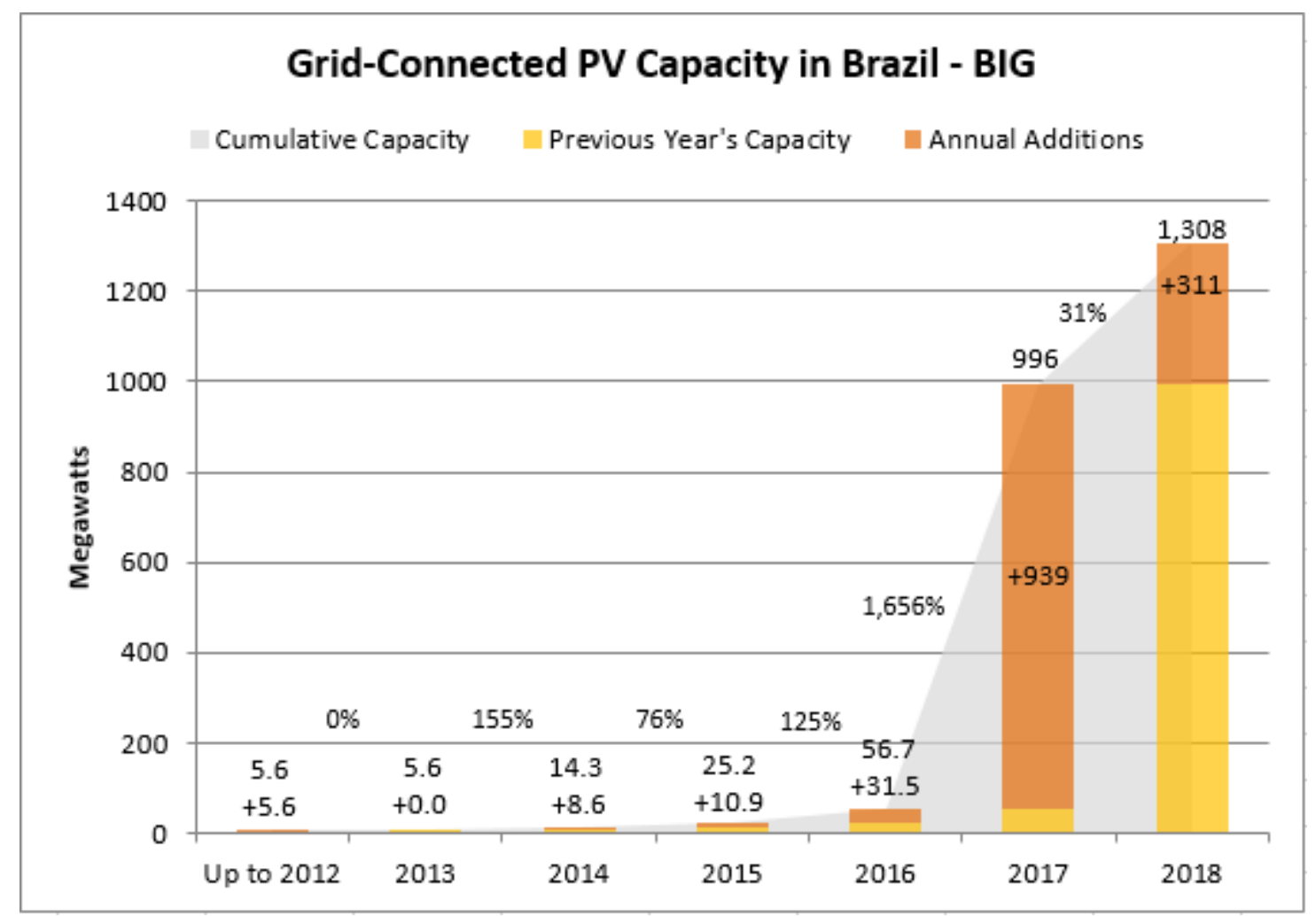

Figure 2 - Evolution of installed power in centralized photovoltaic generation in Brazil. Source: Data compiled by the authors based on [5].

By joining these two graphs it is possible to obtain the current situation of this power source, as shown in the graph of Figure 3. The value of the added capacity of PVSGCs presented for the year 2018 refers until the date of $07 / 31 / 2018$, resulting in a total installed power in Brazil, until this date, of $1.65 \mathrm{GWp}$.

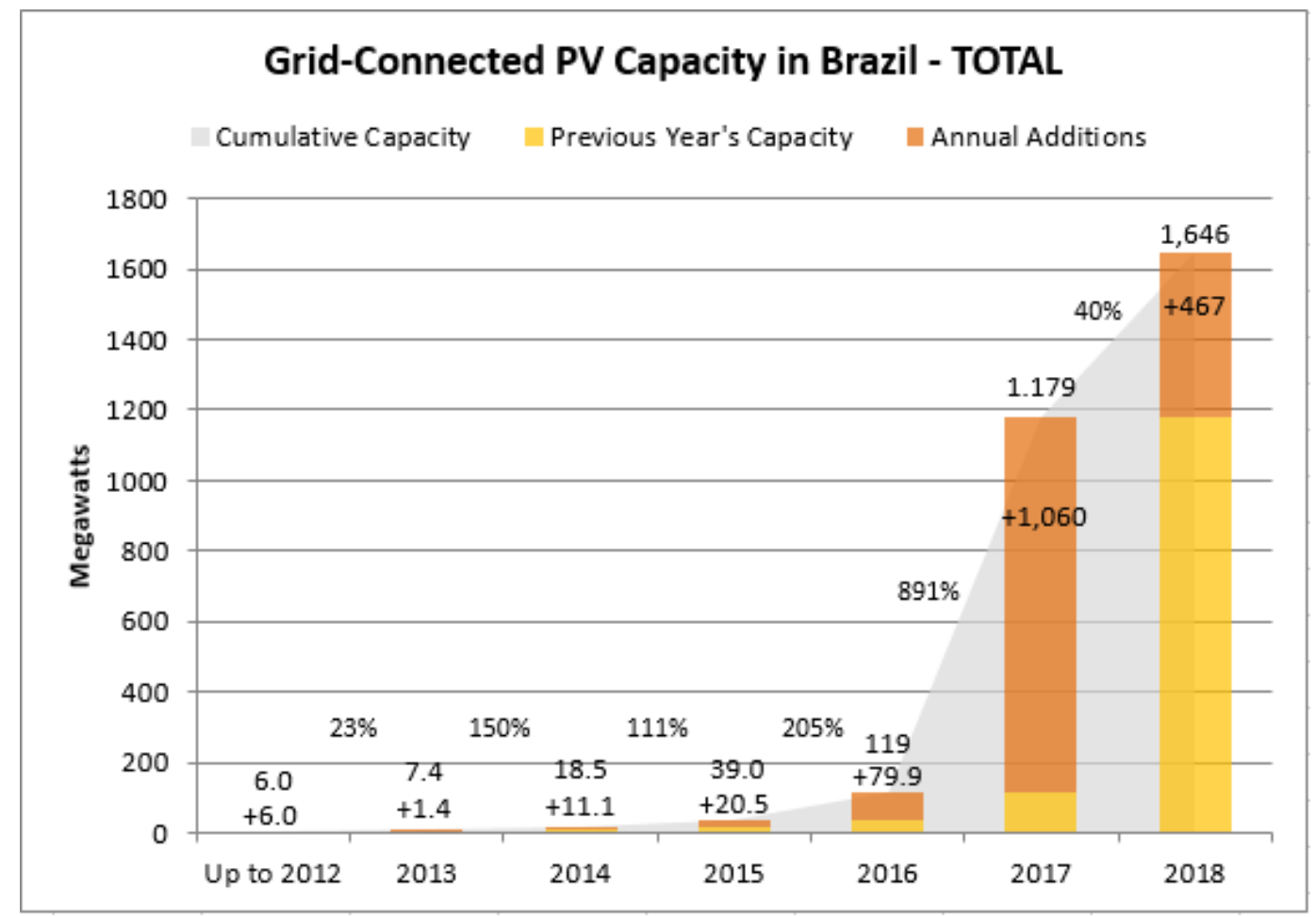

Figure 3 - Evolution of installed photovoltaic power in Brazil.

Source: Data compiled by authors based on [4] and [5]. 
According to [4], the total power installed in Brazil, encompassing all sources of electric power, is 159.97 GW. Considering the installed capacity of PVSGCs, this results in approximately $1 \%$ of the installed power of electricity-generating sources connected to the National Interconnected System (SIN).

An important concept to be defined at this point in the study is the differentiation of the percentage of installed power and the percentage of energy supplied to the electrical matrix. In 2017, the amount of electricity offered in the SIN was 624.3 TWh. From this value, 832 GWh was generated by photovoltaic systems, which represented approximately $0.13 \%$ of the total [7].

The year 2018, although still in progress, also presents a considerable increase in the value of added photovoltaic power. Figure 4 shows the percentage share of electricity available in Brazil in the year 2017 by type of source.

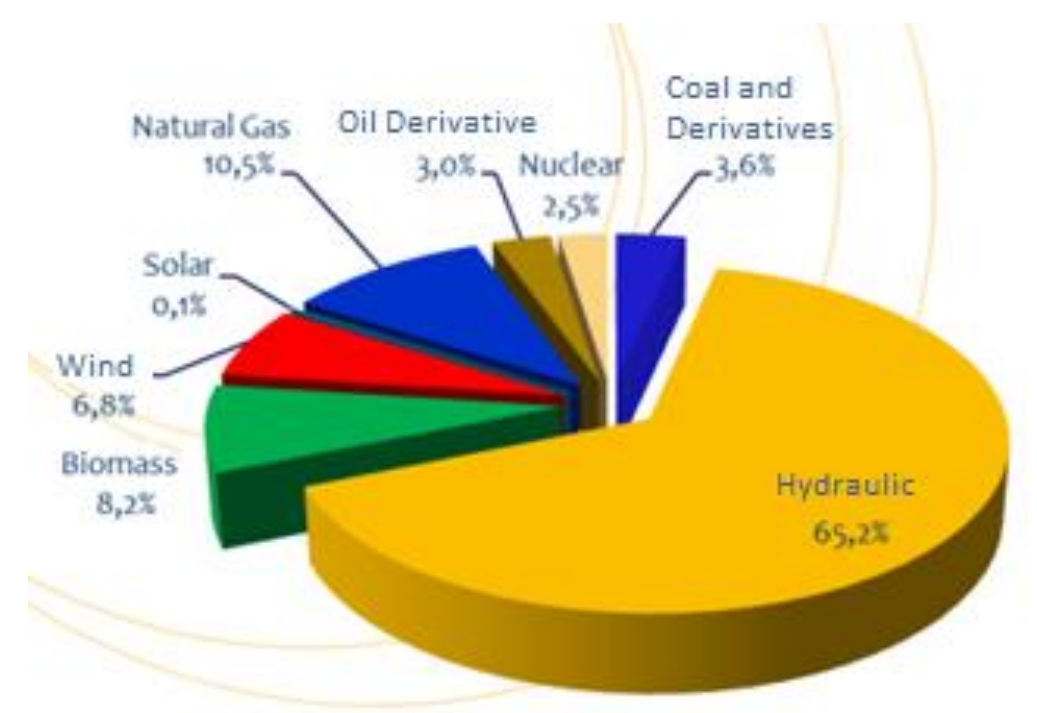

Figure 4 - Percentage distribution of electric energy in Brazil by type of source. Source: Adapted from [7].

As observed in Figure 4, the percentage of solar photovoltaic energy use is still insignificant in the Brazilian electrical matrix compared to other sources, such as hydro and thermal. So photovoltaic solar energy has great growth potential in the country.

From the date of $07 / 31 / 2018$, the values shown correspond to a possible scenario for photovoltaic solar energy in Brazil.

\section{DISCUSSION}

The increase of photovoltaic solar energy in Brazil, as can be observed in the graphs of Figures 1, 2 and 3, which report the current scenario, still does not follow a fixed pattern or a sustainable growth. There are large variations in the percentages of growth over the years, both in the distributed generation systems and in the plants. This fact is more visible in the centralized generation, because when large plants are built, as from 2016 to 2017, the added amount of power has a great jump compared to the previous year.

This characteristic of irregular growth, apparently unpredictable, of photovoltaic solar energy in Brazil can be explained because this technology has recently been regulated. In the initial moments, any value-added power causes great variation in the total value. Therefore, the observed jumps occur in the graphs, which correspond to sharp percentage variations from year to year. 
But worldwide, technology is already established and growing steadily. The percentage added of the installed power annually follows around 30\% concerning the previous value [8]. The trend is that over the years the countries in which technology is still starting to reach this percentage of sustainable growth.

Particularly in Brazil, the percentage of growth is still very high because it has low power installed in its territory. However, as the photovoltaic solar energy in Brazil is gaining representativeness on the energy park, its growth will stabilize, following the world trend. In this way, it is expected that the percentage will decrease gradually for the following years until arriving in 2025. The graph of Figure 5 shows the estimated value of installed power in Brazil until 2025 and how much would be added annually.

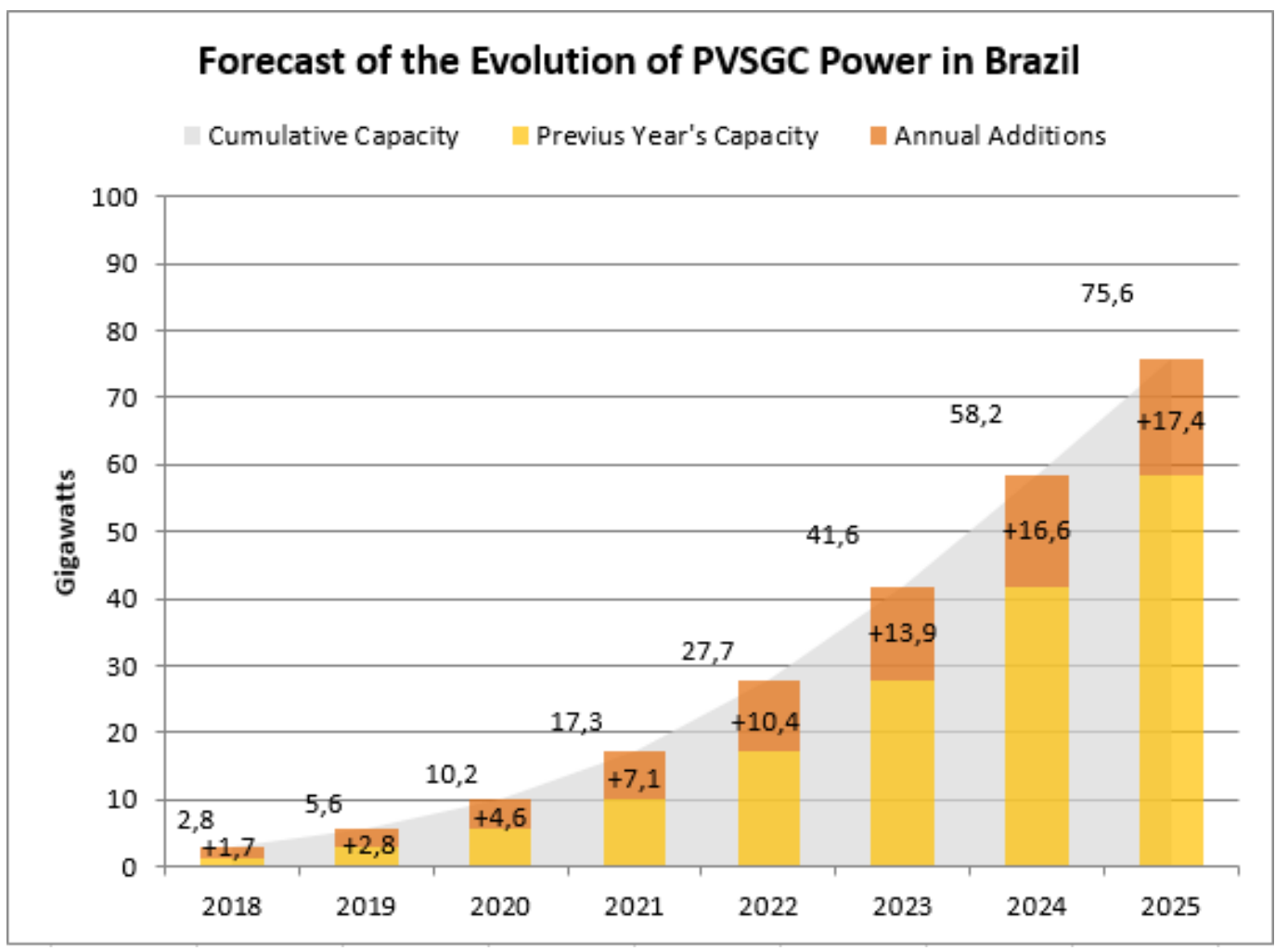

Figure 5 - Forecast scenario of the evolution of the total PVSGC in Brazil in the horizon 2025. Source: Own authorship.

In the graph of Figure 5, a power installed in Brazil for the PVSGCs of 75.6 GWp in 2025 is projected. Thus, using a mean YIELD of $1,300 \mathrm{kWh} / \mathrm{kWp}$.year assigned in this study, we obtain the energy value to be produced that year, resulting in 98.3 TWh of electricity.

According to [9], the estimate of the electric energy that will be demanded by the country in 2025 will be around 800 TWh. If this amount of energy, 98.3 TWh is produced by photovoltaic solar energy, this will represent $12.3 \%$ of the total electric energy demanded in the country in that year, an expressive but feasible part of being reached. However, with the expressive increase in demand, energy production must also increase in the same proportion. Due to its great growth potential, photovoltaic solar energy should be considered as an extremely viable option of electric power supply.

\section{CONCLUSION}

Through the development of this work, it was possible to characterize the current panorama and create a scenario with the prediction until the year 2025 of PVSGCs in Brazil.

Currently, it is noted that the installed capacity of mini and micro-generation PVSGCs has increased steadily, while in centrally-generated plants the increase in installed power is more discontinuous. Therefore, the growth of photovoltaic solar energy in Brazil, represented by the sum of the capacities of mini and micro-generation PVSGCs and 
centralized generation plants, still does not follow a fixed pattern or a sustainable growth. This scenario is justified because it is a new and recently regulated technology.

Another relevant aspect of this study was to identify that the growth forecasts for PVSGCs in Brazil released by Brazilian official bodies were overcome, especially in the years 2016 and 2017, a year in which not only reached $1 \mathrm{GWp}$ of installed capacity, but also in this same year was added more than $1 \mathrm{GWp}$ as seen in the graph of Figure 3.

About the prediction of the growth of PVSGC in Brazil, it is expected that with the maturation of this technology the growth of installed power will become relatively stable. Despite the low expressiveness of photovoltaic solar energy in the current Brazilian electricity matrix, this source has great potential for growth in the country. The forecast indicates that energy from this source could reach around $12.3 \%$ of the total electric energy demand in 2025 in Brazil.

\section{REFERENCES}

1. Tonin, F. S. Caracterização de Sistemas Fotovoltaicos Conectados à Rede Elétrica na Cidade de Curitiba (Characterization of Photovoltaic Systems Grid Connected in Curitiba). [dissertation] Universidade Tecnológica Federal do Paraná (UTFPR), Curitiba, 2017.

2. Scolari, B.; Urbanetz Jr, J. Panorama dos Sistemas Fotovoltaicos Conectados à Rede Elétrica amparados pela REN nํ482/2012 da ANEEL no Brasil (Overview of Power Gridconnected Photovoltaic Systems supported by ANEEL REN No. 482/2012 in Brazil). VII Congresso Brasileiro de Energia Solar - VII CBENS, Gramado, 2018.

3. Agência Nacional de Energia Elétrica [Internet] Nota Técnica ํㅡo 0056/2017-SRD/ANEEL Atualização das Projeções de Consumidores Residenciais e Comerciais com microgeração solar fotovoltaicos no horizonte 2017 - 2024 (Technical Note No. 0056/2017-SRD / ANEEL - Updated Residential and Commercial Consumer Projections with photovoltaic solar microgeneration for 2017 - 2024). [cited 2018 Oct 05]. Available from: http://www.aneel.gov.br/documents/656827/15234696/Nota+T\%C3\%A9cnica_0056_PROJ E\%C3\%87\%C3\%95ES+GD+2017/38cad9ae-71f6-8788-0429-d097409a0ba9 .

4. Agência Nacional de Energia Elétrica [Internet] Outorgas e Registros de Geração: Unidades Consumidoras com Geração Distribuída (Grants and Registers of Generation: Consumer Units with Distributed Generation). [cited 2018 Oct 10]. Available from: http://www2.aneel.gov.br/scg/gd/gd.asp .

5. Banco de Informações de Geração (BIG) [Internet] Agência Nacional de Energia Elétrica. [cited 2018 Oct 10]. Available from:

http://www2.aneel.gov.br/aplicacoes/capacidadebrasil/capacidadebrasil.cfm .

6. Pereira, E. B., Martins, F. R., Gonçalves, A. R., Costa, R. S., Lima, F. J. L., Ruther, R., Abreu, S. L., Tiepolo, G. M., Pereira, S. V., Souza, J. G. Atlas Brasileiro de Energia Solar (Brazilian Atlas of Solar Energy). São José dos Campos, 2017.

7. Ministério de Minas e Energia [Internet] Balanço Energético Nacional 2018: Relatório Síntese: Ano Base 2017 (National Energy Balance 2018: Summary Report: Base Year 2017). [cited 2018 Oct 12]. Available from: http://www.epe.gov.br/sites-pt/publicacoesdados-abertos/publicacoes/PublicacoesArquivos/publicacao-303/topico-

397/Relat\%C3\%B3rio\%20S\%C3\%ADntese\%202018-ab\%202017vff.pdf .

8. REN21, Renewables 2018 [Internet] Global Status Report. [cited 2018 Aug 06]. Available from: http://www.ren21.net/wp-content/uploads/2018/06/17-

8652_GSR2018_FullReport_web_final_.pdf .

9. Tiepolo, G. M., Pereira, E. B., Urbanetz Jr. J., Pereira, S. V., Gonçalves, A. R., Lima, F. J. L., Costa, R. S., Alves, A. R. Atlas de Energia Solar do Estado do Paraná. Curitiba (Solar Energy Atlas of the State of Paraná. Curitiba), 2017. 